Proceedings of the Prehistoric Society 81, 2015, pp. 179-198 (C) The Prehistoric Society 2015. This is an Open Access article, distributed under the terms of the Creative Commons Attribution licence (http://creativecommons. org/licenses/by/4.0/), which permits unrestricted re-use, distribution, and reproduction in any medium, provided the original work is properly cited.

doi:10.1017/ppr.2015.5 First published online 10 June 2015

\title{
The Unsuspected Circles. On the Late Recognition of Southern Iberian Neolithic and Chalcolithic Ditched Enclosures
}

\author{
By VÍCTOR JIMÉNEZ-JÁIMEZ ${ }^{1}$
}

Neolithic ditched enclosures appear to be widely distributed across Central and Western Europe, and from the Mediterranean area to Scandinavia. They have been known in areas of Europe for a long time, but particularly in the last 25 years studies on British, French, Central European, and Scandinavian ditched enclosures have flourished. In line with this, a number of international meetings occurred in the last three decades. In southern Iberia, by contrast, ditched enclosures only began to be known in the 1970s, and even then methodological deficiencies and lack of funding hampered their characterisation. As a consequence of this, Iberian Neolithic and Copper Age ditched enclosures were largely unknown outside Portugal and Spain. They were not represented in any of the international meetings above, nor included in any of the syntheses made about the topic. Not only that, for decades, Spanish and Portuguese archaeologists were not aware of the potential analogies themselves, and the research that was being carried out elsewhere in Europe had almost no influence on the way ditched enclosures were surveyed, excavated, and interpreted in the peninsula. The main objective of this article is to advance the recognition of the southern Iberian evidence by other European researchers and the integration of the Iberian conversation into the general discussion. The focus will be on how these sites have been studied by several generations of Iberian archaeologists, in an attempt to explain why it has taken Portuguese and Spanish archaeologists so long to realise that Iberian enclosures should not be understood in isolation.

Keywords: Archaeology, prehistory, Neolithic, Chalcolithic/Copper Age, Iberian Peninsula, aerial archaeology, remote sensing, geophysical survey, diffusionism, monumentality, ditched enclosure

Due to their intriguing features and monumental character, Neolithic ditched enclosures are generally considered key to understanding the processes of social change in Europe from the first farming communities of the Neolithic to the societies of the Bronze and Iron Ages. The issue goes well beyond the boundaries of the traditional archaeological regions of Europe. They appear to be widely distributed, in diverse forms, across Central and Western Europe, and from the Mediterranean area to Scandinavia. As early as 1930, Cecil Curwen (1930, 42-8) compared

\footnotetext{
${ }^{1}$ Department of Archaeology, University of Southampton, Avenue Campus, Southampton SO17 1BF. Email: V.J. Jimenez-Jaimez@soton.ac.uk
}

British causewayed enclosures with similar sites in France and Germany. By doing so, he was assuming that Neolithic archaeologists in different countries were facing analogous challenges, and was paving the way for future exchange of ideas and methods between British and other European researchers. Later, from the 1980s to the 2000s, a number of international meetings occurred, with contributions from researchers studying sites in the United Kingdom, Ireland, Denmark, France, Germany, and Italy (eg, Burgess et al. 1988; Darvill \& Thomas 2001a; Varndell \& Topping 2002). In such conferences, discussions highlighted both the diversity and the strong links between these regions during the Neolithic (Darvill \& Thomas 2001b, 1). Even though it was 
acknowledged that every site is unique and every region followed its own historical pathway, enough similarities were recognised to accept as natural the sharing of information, the exchange of ideas, and the joint conception and spread of methodological and interpretative innovations.

Roughly at the same time that these conferences took place, numerous prehistoric ditched sites were being discovered in Iberia. Today, dozens of 4 th and 3rd millennia $\mathrm{BC}$ ditched enclosures have been recorded, and more are probable, particularly in the South (Márquez-Romero \& Jiménez-Jáimez 2013; Valera 2013a) (Fig. 1). In terms of the enclosures themselves, there are multiple similarities between these sites and those in other areas of Europe: in form (the circular or oval tendency of their layout) (Figs 2 and 3), features (ditches, pits), formation of archaeological deposits, and chronology, to name just a few. The comparison becomes much more intriguing when considering the 4th millennium cal BC southern Iberian landscape as a whole, for it shows many of the features which characterise the landscapes of the period in other regions: pit sites, megaliths, lithic scatters, rock art, etc.
In spite of this, Iberian ditched enclosures were not represented in any of the international meetings above, nor included in any of the syntheses made about the topic (only some walled, non-ditched enclosures were described, for example in Whittle 1996, 334-8; Andersen 1997, 144-5). The exclusion of the Iberian evidence by non-Iberian archaeologists can be explained by a confluence of several factors. The aforementioned conferences were organised in the United Kingdom by British archaeologists, naturally inclined to relate the British evidence with nearby areas in mainland Europe in their enquiries about phenomena like the process of Neolithisation or the development of the Megalithic tradition. Moreover, accessing the Iberian data was rather difficult for most non-Iberian archaeologists. The results of the fieldwork activities that led to the discovery of the Southern Iberian ditched sites were very rarely properly published. The development of rescue and contract archaeology produced a lot of grey literature, interim reports, and summaries in regional journals such as the Anuario Arqueológico de Andalucía, often hard to find in European libraries. A language barrier made

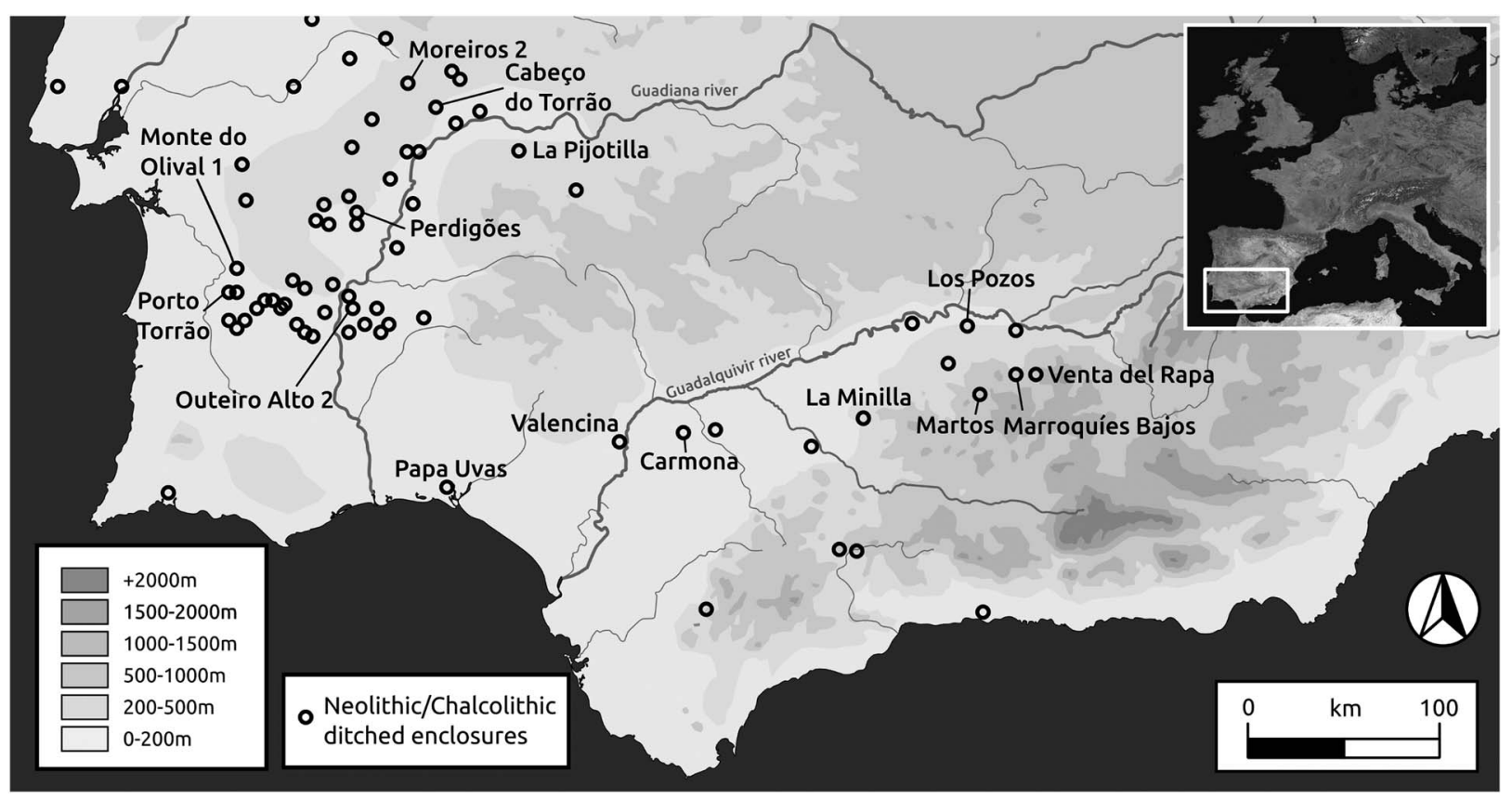

Fig. 1.

Map showing the geographical distribution of Neolithic and Copper Age ditched enclosures in southern Iberia, with indication of the sites mentioned in the text (background satellite image of Europe by Reto Stöckli, NASA Earth Observatory) 

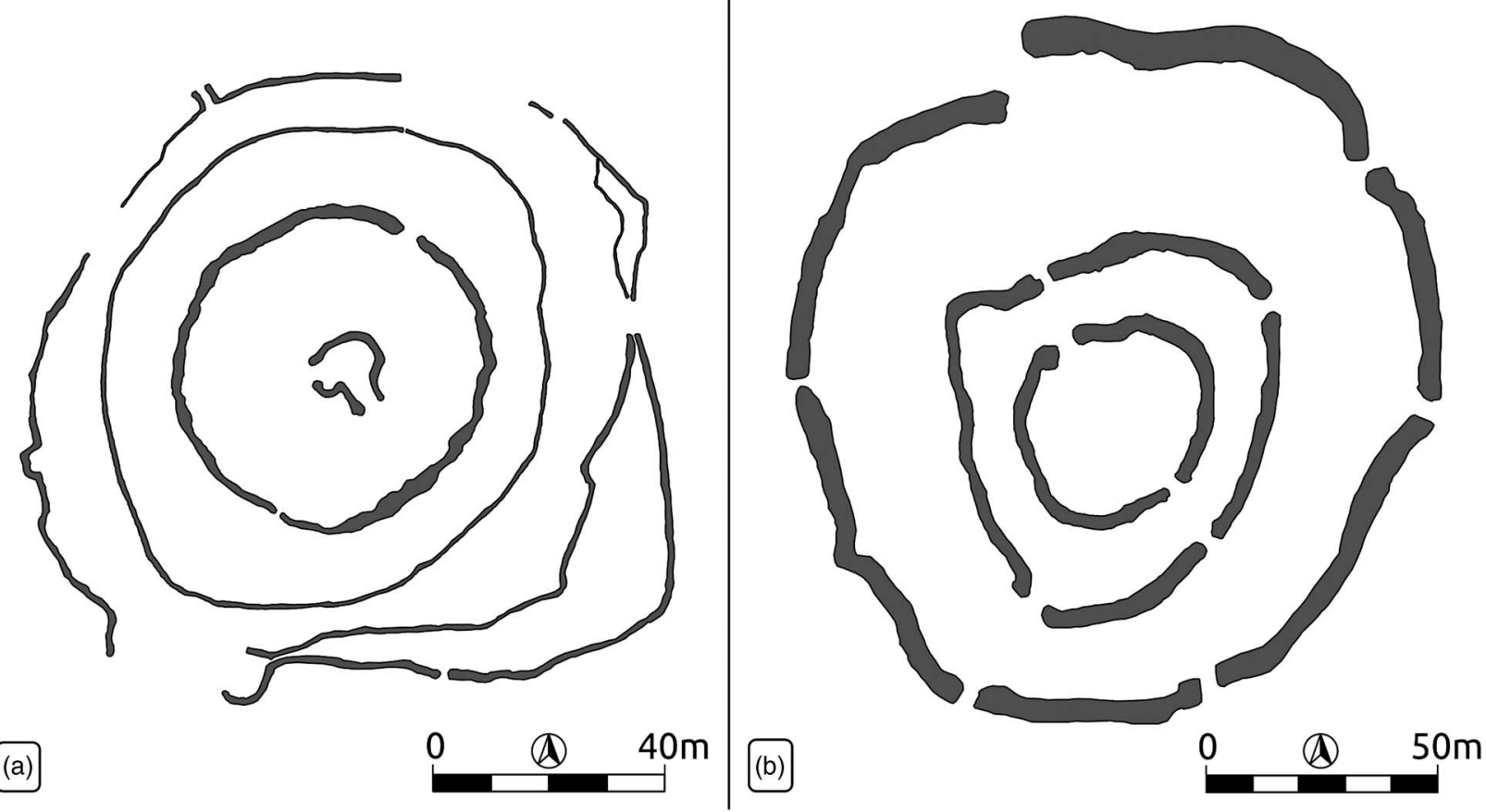

Fig. 2.

Schematic ground plans of two Iberian ditched enclosures, Monte do Olival 1 (Ferreira do Alentejo, Portugal) and Casetón de la Era (Villalba de los Alcores, Valladolid, Spain). The thinner lines might represent the foundation trenches of palisades, instead of proper ditches. Drawn by the author from information in: a) Becker et al. 2012, fig. 7; b) Gibaja et al. 2012, fig. 3

things worse, for those papers were almost without exception written in Spanish or Portuguese. But there is another, more powerful reason for this breakdown in communication. For decades, Spanish and Portuguese archaeologists were not aware of the similarities themselves, and the research that was being carried out elsewhere in Europe had almost no influence on the way ditched enclosures were surveyed, excavated, and interpreted in the peninsula. If Iberian sites were absent from debates in the continental scene it was, above all, because simultaneously the European sites were being left out of the Iberian conversation.

The isolated character of southern Iberian enclosures research in the 1980s and 1990s led to multiple problems. Because expectations about their widespread distribution in Neolithic and Chalcolithic landscapes, their layout and other features were almost non-existent, very few, if any, systematic projects included their identification among their research aims. A majority of ditched sites were therefore discovered via all-encompassing surveys or simply by chance or after partial destruction. At the same time, without the experience that other European archaeologists had accumulated from decades of research on similar sites, effective methods like aerial or geophysical survey, widely applied to ditched enclosures in other areas of the continent, were not employed to characterise vast sites in Southern Iberia such as Marroquíes Bajos (Zafra et al. 1999), Valencina de la Concepción (Fernández \& Oliva 1980) or Porto Torrão (Arnaud 1993) at the time of their discovery. As regards interpretation, traditional categories like that of 'fortified settlement' were uncritically applied, and debates developed in the absence of regular references to alternative views discussed elsewhere. The situation only began to change in the first decade of the 21st century (eg, Delibes 2001, 300-1; Márquez-Romero 2001; 2003; 2006; 2007; Márquez-Romero \& Fernández 2002; Díaz-del-Río 2003; 2004; Rojo et al. 2008; Orozco 2009; Delibes et al. 2009; 2010; MárquezRomero \& Jiménez-Jáimez 2010a; 2010b; Valera \& Evangelista 2010).

The main objective of this article is to advance the recognition of the Iberian evidence by other European researchers and the integration of the Iberian 
conversation into the general discussion. For this I am relying on recent works where an overview of the southern Iberian evidence aimed at an international audience has been given (Márquez-Romero \& Jiménez-Jáimez 2013; 2014). In contrast with these, in the present paper the focus will not be on the enclosures, their features, context, and chronology, as much as it will be on how they have been studied by several generations of Iberian archaeologists. In what follows, I will try to explain why it has taken Portuguese and Spanish archaeologists so long to realise that southern Iberian enclosures should not be understood in isolation.

To illustrate my arguments, I shall make use of comparison. It is important to note that comparison does not necessarily lead to analogy; paying attention to dissimilarities and attempting to find out why they exist can be as fruitful, or even more so, as finding regularities. In fact, this paper intends to find, underline, and explain differences in the histories of research of ditched enclosures in Iberia as opposed to other European regions. The long chronology of southern Iberian ditched enclosures makes them contemporary with later Neolithic sites in Europe - eg, henges, palisade enclosures, or walled enclosures -, in addition to earlier Neolithic causewayed enclosures. However, because of the absence of preserved earthworks at most causewayed enclosures, similar to Iberian ditched enclosures, and because of their widespread distribution, in contrast with more localised developments such as henges, earlier Neolithic causewayed enclosures are a better subject for comparison. Britain will be mentioned very often, given that British causewayed enclosures are well-known (eg, Burgess et al. 1988; Thomas 1999, 38-45; Darvill \& Thomas 2001a; Oswald et al. 2001; Varndell \& Topping 2002; Bradley 2007, 69-77; Whittle et al. 2011) and that research in the UK followed a specific path that greatly differs from that in Spain and Portugal (Oswald et al. 2001, 9-34). Other areas will also be discussed. First, however, I shall very briefly describe the main features of such enclosures.

\section{DITCHED ENCLOSURES IN SOUTHERN IBERIA: AN OVERVIEW}

Ditched enclosures have now been found in almost all Iberian regions, but there seems to be a higher concentration in the central plateau (Meseta Central), the East (Levante) and, particularly, the South, where most fieldwork has been carried out. Both visual inspection of radiocarbon dates and changes in material culture assemblages strongly indicate that Iberian ditched enclosures were a long-lasting phenomenon in the prehistory of the peninsula. They must then be understood in time, not least in southern Iberia, which is where the focus will be in this paper.

Although there are earlier examples in other Iberian regions (eg, Bernabeu et al. 2003; Valera 2013a, 100-1), the construction of ditched enclosures in Southern Iberia took off during the second half of the 4th millennium cal BC (Márquez-Romero \& JiménezJáimez 2010b, 198-204; 2013, 455; Valera 2013b, 338). Moreiros 2 (Arronches, Portugal; Valera et al. 2013), Cabeço do Torrão (Elvas, Portugal; Lago \& Albergaria 2001), and the earlier acts of ditchdigging at Perdigões (Reguengos de Monsaraz, Portugal; Lago et al. 1998; Márquez-Romero et al. 2011; Valera et al. 2014) (Fig. 3), Porto Torrão (Ferreira do Alentejo, Portugal; Valera \& Filipe 2004; Valera 2013c), Papa Uvas (Aljaraque, Huelva, Spain; Martín de la Cruz 1985; 1986), and Martos (Jaén, Spain; Lizcano et al. 1991-2; Lizcano 1999) are the ones which have provided more information so far.

Southern Iberian Late Neolithic ditched enclosures were often located in river basins like those at Guadiana and Guadalquivir (Fig. 1). Generally speaking, they do not present traces of houses or walls; usually only structures dug in the ground (enclosing ditches, pits) are documented, with sporadic instances of possible foundation trenches for timber palisades. No earthworks in the form of banks have survived, if they ever existed. The size of the enclosed areas varies from less than 1 ha to around $10 \mathrm{ha}$, while the dimensions of the ditches range from $1 \mathrm{~m}$ to $6 \mathrm{~m}$ in width and $1 \mathrm{~m}$ to $3 \mathrm{~m}$ in depth, although the average Late Neolithic ditch would be around $2 \mathrm{~m}$ wide and $2 \mathrm{~m}$ deep. The profile of the ditches is normally either U- or V-shaped. Most pits are approximately circular, $1-2 \mathrm{~m}$ in both depth and diameter. Pit and ditch fillings usually contain complex assemblages comprising stone blocks of varied types and sizes, artefacts such as ceramic sherds, flint tools, and knapping waste, or quern stones, often broken or incomplete, and animal and human remains.

During the Early Chalcolithic (first half of the 3rd millennium cal BC) of southern Iberia, the main characteristics of ditched enclosures mentioned above remained more or less constant, at least for most sites. However, there was a substantial increase in the 


\section{V.J. Jimenez-Jaimez. UNSUSPECTED CIRCLES: S. IBERIAN DITCHED ENCLOSURES}

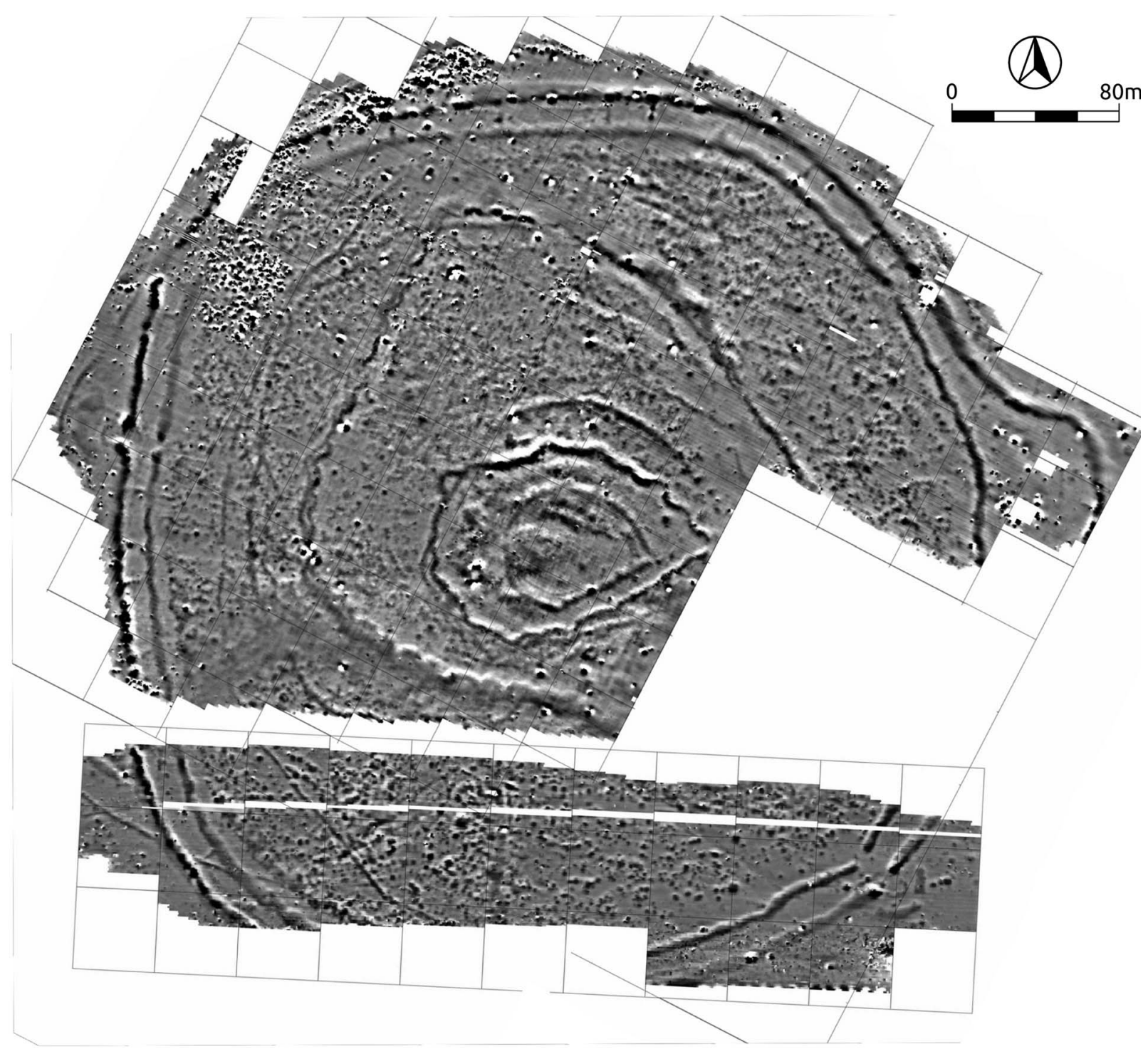

Fig. 3.

Magnetogram of Perdigões (Reguengos de Monsaraz, Portugal), obtained during the 2009 survey (adapted from MárquezRomero et al. 2011, fig. 5)

interior areas, so much so that some of the ditched circuits of the period enclosed spaces which surpassed 70 ha. The ditches also grew on average, reaching up to $8 \mathrm{~m}$ in width and $7 \mathrm{~m}$ in depth on occasions. Even the pits seem to be generally larger in this period. Many of the pits and ditches scattered across more than 400 ha in Valencina de la Concepción (Seville, Spain; Vargas 2004; García Sanjuán 2013) could be attributed to this period, according to material culture elements in their fillings and a number of radiocarbon dates.
Also worth mentioning are Marroquíes Bajos (Jaén, Spain; Hornos et al. 1998; Zafra et al. 1999; 2003), La Pijotilla (Badajoz, Spain; Hurtado 1986; 2003; 2008), and later phases of building activity at Perdigões, Porto Torrão, and Papa Uvas (see references above), amongst many others.

By the time Beaker pottery began to circulate in Iberia, towards the middle of the 3rd millennium cal $\mathrm{BC}$, new transformations occurred. In the south, evidence dating from the Late Chalcolithic 
(second half of the 3rd millennium cal BC) is ambiguous. On one hand, some newly built ditched sites appeared after c. $2500 \mathrm{cal}$ BC (eg, Valera 2013b, 339; Lechuga et al. 2014). On the other hand, some of the most outstanding places from the previous phases continued to be loci of human activity, as multiple pits and episodes of recutting seem to prove. More importantly, further rings, usually concentric in relation to the old ones, were often added to those few places of enduring relevance. No banks are directly known; whether or not they originally existed is debatable, but there is indirect evidence of their presence next to some of the Late Chalcolithic ditches at Perdigões (MárquezRomero et al. 2011, 183). Crucially, circular, stonebased houses, and stone masonry walls similar to those typical of the aforementioned walled enclosures, including towers and bastion-like features, began to appear at some of these ditched enclosures. However, their chronology and therefore their relationship with ditches and pits often remain unclear.

\section{THE LATE DISCOVERY OF SOUTHERN IBERIAN DITCHED ENCLOSURES}

When comparing the history of research on prehistoric ditched enclosures in Southern Iberia with that elsewhere, one of the most remarkable aspects is the very long delay in the discovery of Iberian sites relative to European sites, and particularly, British ones (Fig. 4).

In Britain, enclosed sites that are nowadays considered Neolithic began to attract the attention of antiquarians as early as the 18th century (for full references see Oswald et al. 2001, 9-34). Interestingly, these sites that we today call causewayed enclosures were enclosures surviving as earthworks, that is, they possessed visible above-ground structures such as banks. Therefore, they were easily identifiable at ground level through field walking. In the late 19th century, as the discipline of archaeology developed in Britain, ideas about these 'prehistoric camps' began to be based on more robust data coming from survey and excavations. In the 1920s, the excavations at Windmill Hill by Keiller introduced new methods of excavation and recording that confirmed the existence of Neolithic causewayed enclosures.

In France, as early as 1924, Déchelette mentioned six known instances of enceintes néolithiques, and claimed that they were numerous in the hilly parts of France. He cited the existence of Neolithic graves and an earthen rampart at Vaudois, as well as the frequent presence, in great quantity, of remains of later periods located on top of old Neolithic enclosures (Déchelette 1924, 368-71), all of which perhaps made these sites visible enough for surveyors to find them. By that time a few sites were also known in Germany (Curwen 1930, 44-8; Hodgson 1988, 363), and just after the Second World War, a large number of Neolithic enclosures were identified in Southern Italy (Bradford \& Williams-Hunt 1946). By contrast, in Iberia the first ditches were detected in Andalusia (Southern Iberia) in the 1970s, and the results of the first excavations were not published until the 1980s. The earliest examples are Valencina de la Concepción (Fernández \& Oliva 1980; 1985; 1986; Ruiz Mata 1983), Papa Uvas (Martín de la Cruz 1985; 1986), and La Pijotilla (Hurtado 1986). In Portugal, knowledge of ditched sites was rather limited until 1997, when Perdigões was discovered (Lago et al. 1998).

It is evident that the discovery of prehistoric ditched sites took place much later in Spain and Portugal than in other European regions. The absence of visible, above-ground earthworks next to the Iberian ditches - probably due to a more continued agricultural use of the land - made their detection by field walking surveyors harder. Further, from the 1930s to the 1980s, the social, economic, and political orders in Spain and Portugal were very different to those in the countries referred to above. In Iberia, the economy was underdeveloped and political rights were restricted by dictatorial regimes; insufficient funding and political control hampered archaeological research. The end of the dictatorships in the 1970s brought about new economic conditions that allowed the building of new residential areas, the construction of large infrastructures, and the funding necessary for undertaking extensive excavation projects. It is no surprise, therefore, that 4th and 3rd millennium BC ditched sites only began to be documented then.

Other factors beside their late discovery contributed to the lack of communication between Iberian and other European archaeologists as regards prehistoric ditched sites. One of the most notable is a deficient characterisation of southern Iberian prehistoric enclosures due to the application of inadequate methods. In particular, the lack of remote sensing surveys complicated the general consideration of these sites as circular or oval enclosures and therefore the emergence of comparative approaches, as I will show next. 


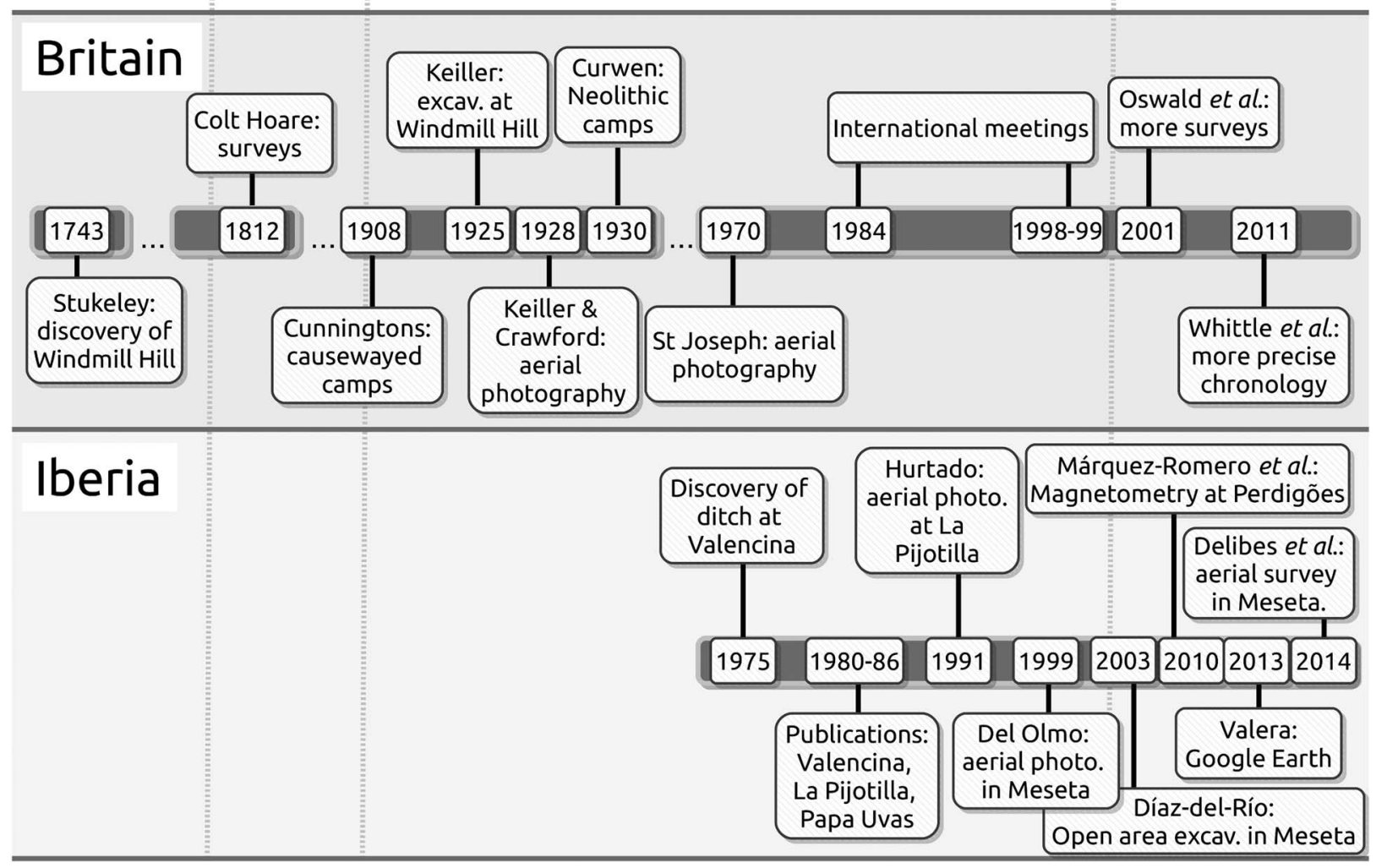

Fig. 4.

Timeline comparing the most significant milestones in the identification and characterisation of both southern British Neolithic causewayed enclosures and southern Iberian Neolithic-Chalcolithic ditched enclosures

\section{A DEFICIENT CHARACTERISATION}

Because, in the absence of preserved earthworks, most prehistoric ditches are virtually undetectable for field walking surveyors from close up, the importance of remote sensing techniques like aerial prospection for Neolithic enclosures research in Europe can hardly be overstated (Brophy 2005). Research on British causewayed enclosures clearly illustrates this. In 1928, Keiller and Crawford published Wessex from the Air, a pioneering work on the use of aerial photography to identify and characterise prehistoric earthworks in southern England. These data eventually resulted in the publication of the article 'Neolithic Camps' by Curwen (1930), where most of these discoveries were discussed. In the 1960s, a more systematic application of the aerial survey technique in England brought about the realisation that Neolithic causewayed enclosures were present not only on the chalk uplands, but also in lowland areas such as river valleys and terraces. Apparently, the non-existence of banks in sites located in lowland areas was due to postdepositional processes; the effects of intensive agriculture on the more fertile alluvial soils of the valley bottoms had made their survival unlikely. In the absence of banks, enclosures in valleys and river terraces were only visible from the air as cropmarks, and not at ground level as earthworks. By 1970, St Joseph had photographed 21 new instances (Oswald et al. 2001, 20, 25-32).

In some regions of the continent analogous processes took place. In France, for example, aerial archaeology developed from the 1950s. In the following decades a good number of Neolithic ditched enclosures were detected thanks to the work of pioneers such as Daniel Jalmain, Roger Agache, or 
Jacques Dassié, among others (eg, see several papers in Bréart 1999). The importance of aerial reconnaissance for the identification of Neolithic enclosures is very clearly seen in Central Europe (eg, Hodgson 1988, 365) and Italy (Musson 2013). In the former, restrictions on non-military flying and air photography produced enormous contrasts in the distribution of sites and, indeed, in the quality of archaeological data on both sides of the Iron Curtain up until the 1990s (Braasch 2002). In the formerly communist countries where those impediments disappeared during the 1980s and 1990s and archaeologists began practising systematic aerial survey, the pace of discovery of Neolithic ditched enclosures exploded (eg, regarding Moravia see Hašek \& Kovárník 1999). In the Italian Tavoliere, Neolithic ditched enclosures were for the first time seen from air in the 1940s. Wartime intelligence air photographs taken by the British Royal Air Force were used by two RAF officials, John Bradford and Peter Williams-Hunt (1946), to identify and map over 200 previously unknown ditched sites in the vicinity of Foggia, despite the almost total absence of visible remains aboveground. Legal restrictions on private flights considerably slowed this process, in spite of the efforts of both Italian and non-Italian researchers, but eventually further studies on post-war photographs increased the number of known Neolithic ditched sites to over 500 (Musson 2013, 29-30).

Even more crucial than their discovery, however, is their characterisation. Indeed, remote sensing techniques also constitute excellent means for the adequate understanding of sites and their features. Their primary advantage is that because of their relative speed and low price per surveyed square unit, archaeologists can look at the 'big picture' for any given site. With them, archaeologists can 'see' the site they study in its entirety or in a large part, and therefore observe its limits, the distribution of features in space, or how these relate to the micro-topography of the place and its surroundings. This has two main benefits. First, information generated by aerial prospection, geophysics, and other non-destructive techniques can be taken later as starting point for planning and executing subsequent fieldwork activities targeted at specific areas - 'minimalist excavation', as Musson $(2013,89)$ puts it. Second, they have the potential to produce high quality contextual data for a better understanding of more particular aspects of research, such as the stratigraphies recorded by excavation, the formation of archaeological deposits and, especially, the samples used to get chronological, environmental, and behavioural data.

Southern Iberian Neolithic and Chalcolithic ditched enclosures, often invisible at ground level and sometimes very large and complex, can benefit a lot from the application of remote sensing techniques that produce wider and more complete pictures - ie floor plans - than those provided by traditional excavation (as has been demonstrated by Márquez-Romero et al. 2011; Valera 2013d; Valera et al. 2013; Delibes et al. 2014). However, until very recently, neither methods based on higher and more intelligible viewpoints eg, aerial/satellite survey -, nor ground-based remote sensing - eg, geophysical survey -, have been nearly as common as other, less inclusive procedures.

As explained earlier, due to economic and political conditions, while this 'aerial archaeology revolution' was taking place in much of Western Europe, in Iberia, aerial survey for archaeological purposes, or even open area excavations, were difficult. Instead, small trenches or sondages were the norm. Coinciding with the advent of democracy, from the late 1970s to the late 2000s an impressive amount of development-led archaeology was carried out in parts of Spain and Portugal, in line with a very intense urban development process largely fostered by a growing tourism industry. A number of ditched sites were identified this way. This new form of archaeological practice slowly began to increase the size of surveyed areas, but for a while these were still too small to observe the enclosed character of the sites and their overall shape, restricted as they were by the urban development environments in which a majority of these excavations were carried out. This occurred at sites like Los Pozos (Hornos et al. 1987) (Fig. 5), La Minilla (Ruiz Lara 1991), Carmona (Gómez Saucedo 2003), Valencina (see references above), and many others. Only from the late 1990s onwards did large, open area excavations become more widespread in southern Iberia (eg, Outeiro Alto 2 in Valera \& Filipe 2010; or Venta del Rapa in Lechuga et al. 2014).

The earliest application of aerial photography to advance the comprehension of a southern Iberian ditched site occurred at the beginning of the 1990s at La Pijotilla (Hurtado 1991), where an enormous ditched circle and what at the time seemed to be an internal semi-circle completed by a stream were identified in the images. Nevertheless, its impact was somewhat limited. The use of aerial reconnaissance as 


\section{V.J. Jimenez-Jaimez. UNSUSPECTED CIRCLES: S. IBERIAN DITCHED ENCLOSURES}

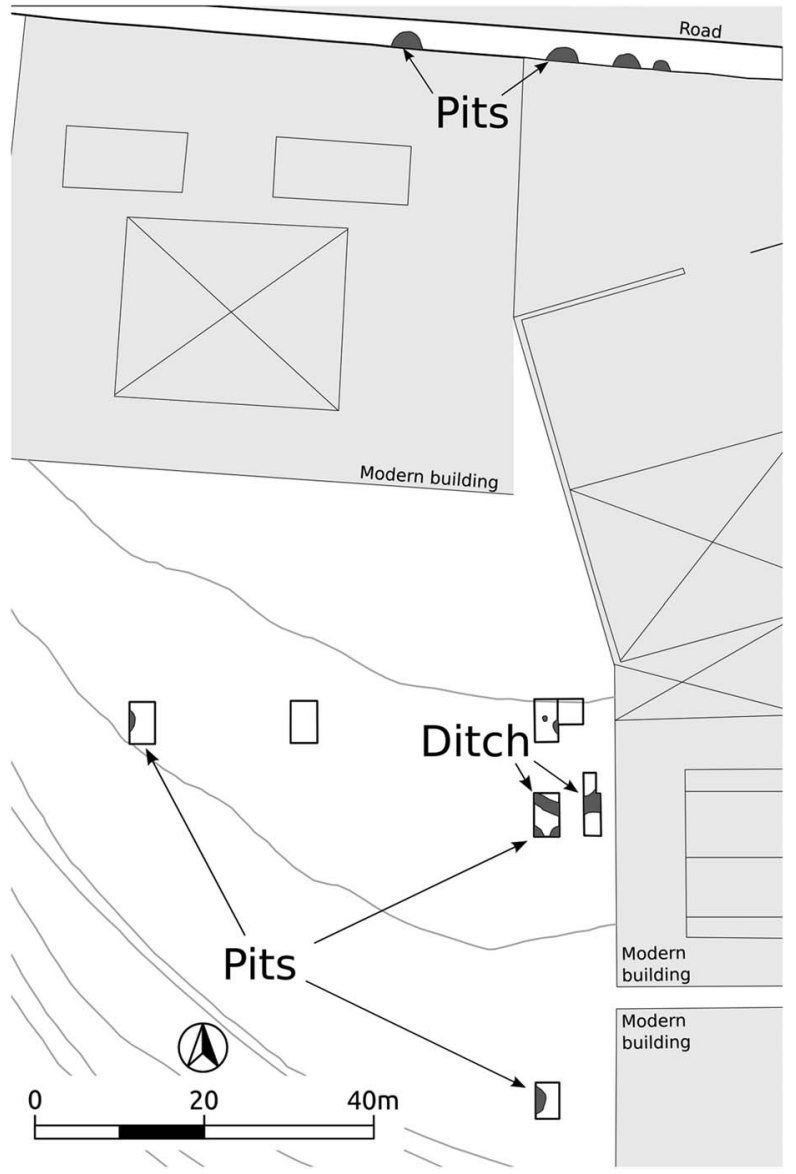

Fig. 5.

Survey areas at Los Pozos (Lahiguera, Jaén, Spain), a good example of the urbanised environment in which many of the archaeological activities that recorded prehistoric ditches in southern Iberia from the 1970s onwards were performed. It is also very illustrative of the restrictive character of small- to medium-size trenches when applied to large enclosure sites

like this: the spatial relationships between features and between these and the topography of the place are very hard to see (modified from Hornos et al. 1987, fig. 1)

a method to detect new sites or to increase knowledge about those already known remained occasional (eg, Perdigões in 1997; Lago et al. 1998). This was the case until very recently, when Valera (2013d) located 19 new sites in southern Portugal, 14 of them already confirmed, by making use of Google Earth images and tools (Fig. 4). The employment of geophysical survey methods followed an analogous path: they had rather limited use until the introduction of magnetometry in the study of Perdigões (Márquez-Romero et al. 2011), Valencina (Wheatley et al. 2012), and several other
Portuguese sites (eg, Valera et al. 2013) in the last few years. Once those techniques were put in practice, the number of known sites and the amount of quality data about them skyrocketed, particularly in southern Portugal (Fig. 6).

In other Iberian regions analogous processes occurred, albeit at a smaller scale. In the East, a few sites were excavated in the late 1980s and early 1990s, such as Niuet, Les Jovades, and Arenal de la Costa (Bernabeu 1993; Bernabeu et al. 1994), but no complete floor plans were recorded. It would be in the late 1990s in the Meseta Central where things would move forward. Several Copper Age ditched enclosures were surveyed employing large scale, open area excavation procedures (Díaz-del-Río 2003; 2004), while dozens of enclosed sites were discovered by Olmo via systematic aerial survey (Olmo 1999); the results of image processing and analysis of these and other photographs have just been published (Delibes et al. 2014). Likewise, in the Northern Meseta, Casetón de la Era has been the subject of extensive geophysical survey (ibid., 42-7) (Fig. 2).

To sum up, due to the abundance of excavations based on relatively small trenches, and the rarity of more inclusive or wider coverage surveys, the identification of the first ditches in southern Iberia through rescue archaeology did not immediately result in the realisation that they formed circular or oval enclosures. In the late 1990s, the assertion that many of them could have adopted a roughly circular and concentric form still constituted an audacious or daring hypothesis (as acknowledged by Castro et al. 2008, 151-52). The general recognition of this would have to wait until the first few years of the new century. This severely limited the capacity of Iberian researchers to perceive similarities with other European enclosures.

\section{A LACK OF COMPREHENSIVE PUBLICATIONS}

A few years after their discovery in the 1970s, a number of southern Iberian ditched enclosures had experienced multiple excavations. Today, 40 years later, the amount of fieldwork conducted, even if difficult to quantify, is undoubtedly huge. Certain sites were the subject of a high volume of archaeological activities. That is the case of Valencina de la Concepción, a 400 ha site where about 100 archaeological activities have been executed (see eg, Vargas 2004; García Sanjuán 2013), or Marroquíes Bajos, a 100 ha ditched enclosure partially 
THE PREHISTORIC SOCIETY
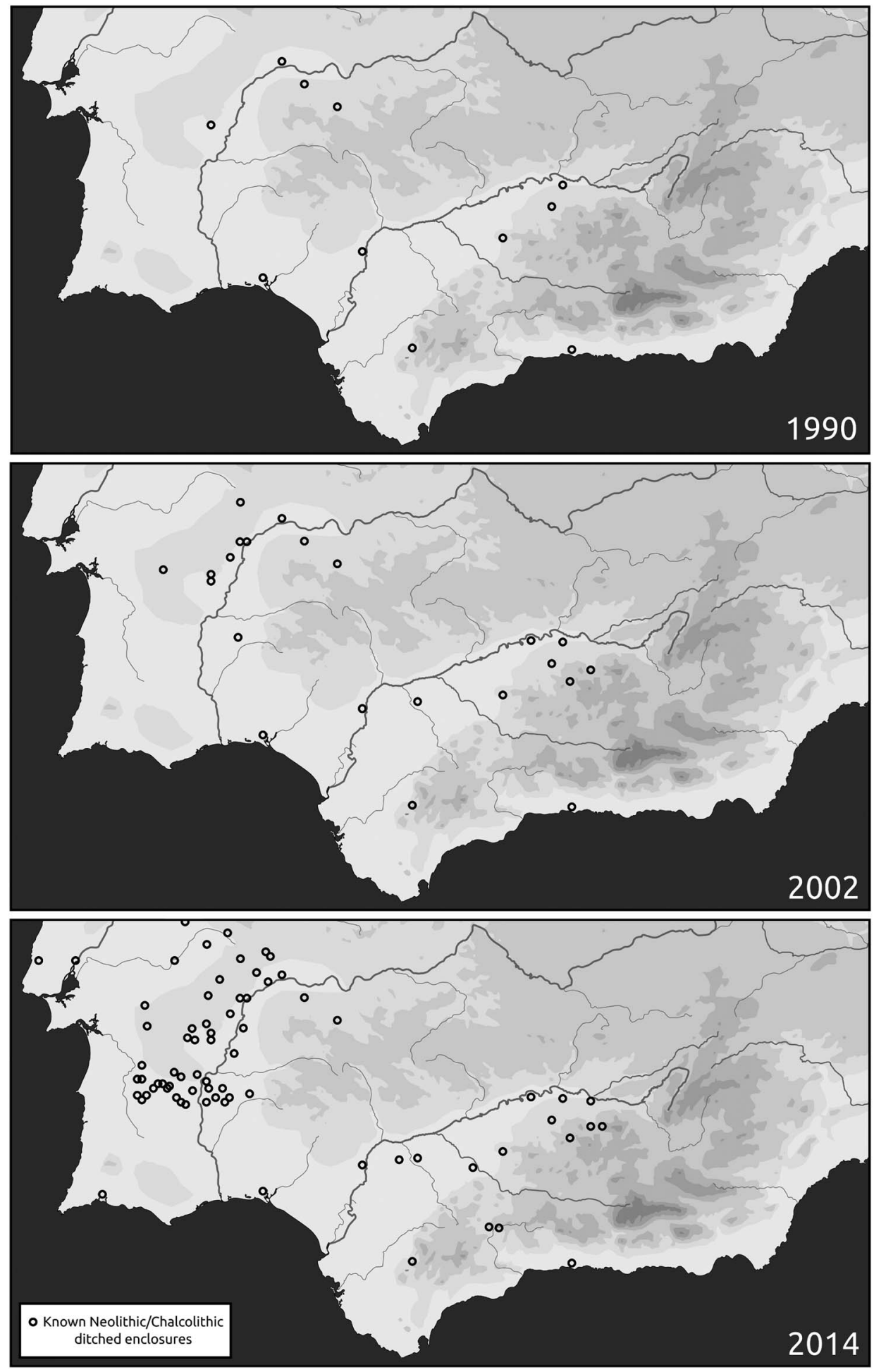


\section{V.J. Jimenez-Jaimez. UNSUSPECTED CIRCLES: S. IBERIAN DITCHED ENCLOSURES}

located beneath the modern city of Jaén, where 271 archaeological activities were undertaken between 1995 and 2002 (Zafra et al. 2003, 80) and a similar number may have been carried out afterwards. Unfortunately, much of this fieldwork is largely irrelevant. Most of it was undertaken by small companies focused on rescue or contract archaeology in difficult conditions, with low budgets and tight deadlines. At Valencina de la Concepción and Marroquíes Bajos, in particular, numerous teams have often worked without proper coordination and definitely without a common database, cartography, methods, or even objectives. Reliable radiocarbon dates are scarce, and zoological, anthropological, and environmental analyses are exceptional.

To make things worse, little of the fieldwork has been properly published. Indeed, this development-led archaeology has not entailed the publication of comprehensive works where extensive details of the excavations are given, further complicating the characterisation of these sites. For example, at Marroquíes Bajos, as late as 2008, only nine short reports had been published, along with a few papers that summarised data from unpublished interim reports (eg, Hornos et al. 1998; Zafra et al. 1999; 2003). By my count, until 2008, 129 publications where southern Iberian ditched sites were more or less the main topic had been made. Of those, only five papers $(4 \%)$ were written in English, the rest being Spanish or Portuguese texts. Seventy $(54 \%)$ were short reports, normally summaries of unpublished interim reports, that mostly described the circumstances in which the archaeological activities had taken place and how they complied with local laws and planning regulations, followed by a brief overview of their most 'representative' findings. Twelve of the total 129 publications $(9 \%)$ were reports presenting the results of specific analyses or studies about particular sites, such as radiocarbon dates, osteological data, or simply outstanding artefacts. Eighteen (14\%) were syntheses about individual sites where the data coming from the short reports were gathered, along with some new information and a variable amount of interpretation.
Twenty-four $(18 \%)$ were syntheses of a particular area or region where ditched sites had been found, which, among other things, briefly presented some unpublished data from fieldwork at ditched sites, or syntheses about specific features shared by most enclosures. Of the total 129 publications, only five (4\%) were close to being full reports from fieldwork at southern Iberian ditched enclosures, including comprehensive descriptions of the excavations, features, and stratigraphies, as well as anthropological, faunal, environmental, or chronological data (eg, Martín de la Cruz 1985; 1986; Lizcano 1999).

Both the application of inadequate methods and the scarcity of dedicated publications hampered the characterisation of most southern Iberian ditched sites as enclosures. But this also has to be understood in relation to the intrinsic complexity of some of these sites, which I will address next.

\section{THE COMPLEXITY OF OCCUPATIONAL SEQUENCES AT SOUTHERN IBERIAN DITCHED ENCLOSURES}

One of the particular features of Iberian enclosures is their longevity as meaningful places. That is more evident if we compare them to enclosures in other areas of Europe. Taking for example British Early Neolithic causewayed enclosures as reference, their short-lived character has been recently highlighted. A large scale study focused on the application of Bayesian statistical methods to radiocarbon dating has refined their chronology, showing that the observance of these practices was rather limited in time within the Early Neolithic, from the late 38th century to the end of the 36th century cal BC, with few exceptions that extend beyond c. $3500 \mathrm{cal}$ ВС (Whittle et al. 2011). They normally comprise one or two concentric circuits, three or four at the most. British causewayed enclosures often show later Neolithic or Bronze Age deposits in the upper parts of their ditches' infills, but substantial reoccupation during the Neolithic is unusual. Later Neolithic monuments such as barrows, cursuses, and henges were, with rare exceptions, located in other places, sometimes in the proximity of

Fig. 6.

Sequence of maps showing the rapid pace of discovery in the last 25 years as regards 4 th and 3rd millennia BC ditched enclosures in southern Iberia (based on Márquez-Romero \& Jiménez-Jáimez 2010b, map 4; and Valera 2013a, fig. 2; with additions). Notice the much slower developments on the Spanish side of the map, especially the Guadalquivir basin, in relation to the Portuguese side (on the left), due to the fact that, with exceptions, wider coverage survey methods are still rarely applied to prehistoric ditched sites in southern Spain 
abandoned causewayed enclosures (eg, Avebury near Windmill Hill), but seldom on top of them (some exceptions eg, in Oswald et al. 2001, 134-7; Bradley 2007, 76-7). In the Bronze (round barrows) and Iron Ages (hillforts), the reoccupation of places where enclosures stood during the Early Neolithic or their surroundings seems to be common, but in those cases the clear contrasts in both features and material culture make it relatively easy to differentiate between contexts corresponding to the 'old' and to the 'new' practices. This generated moderately 'clean' occupational sequences at causewayed enclosures that promoted their recognition, definition, and interpretation.

On the contrary, in Iberia the evidence is definitely 'messier' than in Britain. This is obvious, above all, in southern Iberia, where certain sites exhibit tremendous internal complexity. Understanding this is important to underlining that in Iberia the practice of monumentalising extensive areas by circumscribing them with ditches lasted for a long time; it continued - or cyclically resurfaced - until the end of the 3rd millennium cal BC. In southern Iberia, although some sites have few ditched circuits, and in that sense they may have been as short-lived as British causewayed enclosures, other places were enduringly relevant. It is likely that more than one or two successive spurts of constructive activity are represented, as a sequence, in certain sites. As a result, some ditched sites are massive in terms of enclosed area, high number of circuits, and clearly diachronic sequence of ditch digging, as well as multiple recuttings of old ditches. An additional indicator of longevity is the considerable number of pits with heterogeneous chronologies, often cutting and re-cutting each other. Finally, during the Copper Age, elements normally absent from both British enclosures and Late Neolithic southern Iberian enclosures such as collective burials in tombs, circular houses, or walls, were sometimes added.

Discerning the dynamics of occupation, activity, and abandonment at an archaeological site always requires a deep knowledge of intrasite temporality. Unfortunately, getting 'the beads on the string in the correct order' (Whittle 2006, 21) is more difficult to do for southern Iberian than for British enclosures. This is partly because there are more beads to put together (ditches, pits, tombs, houses, walls) and because they are harder to isolate. Part of it is, however, due to some shortcomings in the Iberian archaeological practice until recently; namely restricted survey areas, which hampered the understanding of stratigraphies and formation processes, limited absolute dating programmes, and almost nonexistent Bayesian approaches. Simply put, the sequences of events at the largest and most cited ditched sites in southern Iberia - ie Valencina de la Concepción, Marroquíes Bajos - are often extremely confusing. Understanding the relationship in time between ditches and between them and other components, such as walls or houses, presents multiple challenges. At this point, new discoveries, when not well dated or contextualised, do not help; they just add noise. I will try to illustrate these issues with one example.

Perdigões (Reguengos de Monsaraz, Portugal) (Fig. 3) is a Neolithic and Chalcolithic site near the Guadiana river, comprising at least 12 roughly concentric ditched enclosures, several hundred pits, a few megalithic tombs clustered between the two outer ditches, a set of standing stones outside the outer circuit and a very complicated assemblage of deposits centred around a large circular structure in the inner area. It is located in one of the richest archaeological landscapes of Iberia, with notable examples of prehistoric monumental architecture such as menhirs and portal tombs (antas). Discovered in 1997 (Lago et al. 1998), António Valera from the Portuguese entity ERA Arqueologia coordinates an international research project centred around the site, within which a team from the University of Malaga in Spain (UMA), led by José Márquez Romero, has been carrying out fieldwork at the site since 2008. In 2009, UMA and ERA undertook a magnetometric survey (Márquez-Romero et al. 2011), resulting in a much clearer picture of the site than is available for most southern Iberian enclosures. It is also the ditched site which offers the most absolute dates in Iberia, with 35 published dated samples at the time of writing (Valera et al. 2014).

The biography of Neolithic and Copper Age Perdigões stretched for over 1200 years (Fig. 7). The fillings of two ditches and two small trenches (possible palisades), all concentric and located in the central area, as well as some pits, were dated to the Late Neolithic (last third of the 4th millennium cal BC), either by visual inspection of radiocarbon dates or by virtue of the typology of the materials unearthed during excavations. In the Early Chalcolithic (first half of the 3rd millennium cal $\mathrm{BC}$ ), two new ditches, whose courses run almost completely in parallel forming the 


\section{V.J. Jimenez-Jaimez. UNSUSPECTED CIRCLES: S. IBERIAN DITCHED ENCLOSURES}

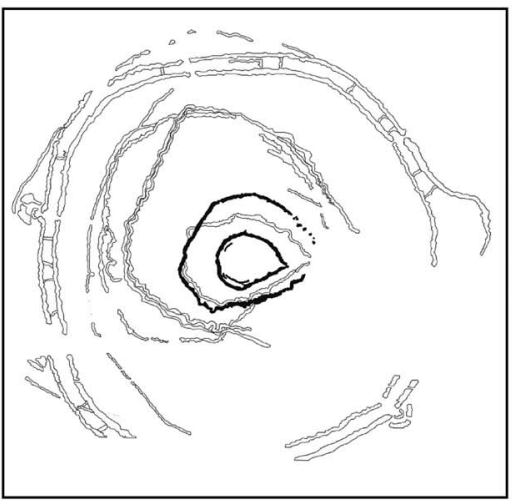

Neolithic Perdigões (3350-2900 BC)

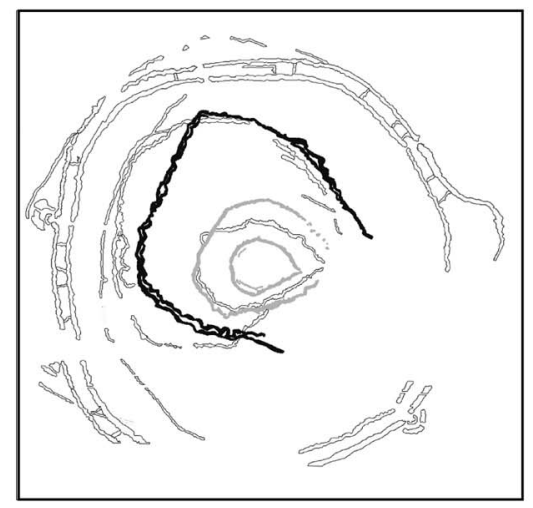

Early Chalcolithic Perdigões (2900-2450 BC)

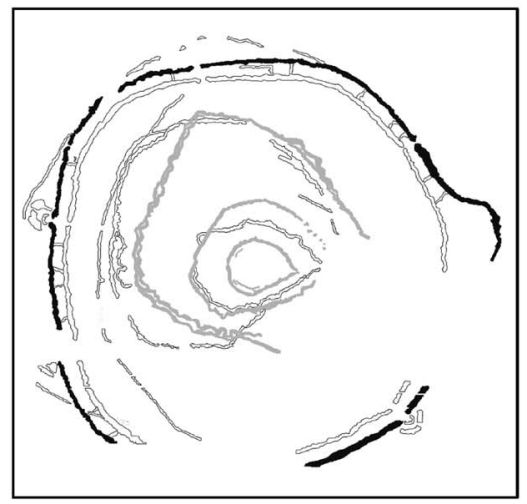

Late Chalcolithic Perdigões (2450-2150 BC)

Undated

Filled during the phase of reference

Extant ditches filled prior to the phase of reference

Fig. 7.

The sequence of enclosing ditches at Perdigões (Reguengos de Monsaraz, Portugal) as currently understood by its excavators (drawn by the author from information in Valera et al. 2014)

intermediate circuits of the site, were filled, together with several pits. A large circular structure, over $20 \mathrm{~m}$ in diameter, was dug and filled with deposits and stones in the central area, and a number of funerary megalithic structures were built outside the enclosures. During the Late Chalcolithic (second half of the 3rd millennium cal $\mathrm{BC}$ ), at least one ditch, the outer one, was filled and probably recut. At some point, complexly dug features near the entrances of the outer ditch were added, posing numerous problems of chronology themselves. Some activity continued in the central area. Most pits and the rest of the known ditches remain undated at the moment. At first sight, the sequence of events and practices at Perdigões seems to be overly intricate. However, while being more complex than any British causewayed enclosure known to date, it might be relatively simple when compared to other southern Iberian sites such as Marroquíes Bajos, where not only ditches, pits, and tombs are present, but also Copper Age houses and walls.

To sum up, questions with straightforward answers in Britain, like, 'is the practice of building ditched enclosures Neolithic in origin?', 'are ditches the only kind of structure employed to delimit Neolithic enclosures?', or 'are houses a typical occurrence of Neolithic ditched enclosures?', have in fact posed significant challenges to Spanish and Portuguese archaeologists for decades, and in some ways continue to do so even today. As this was combined with a certain disregard for external references for comparison (see below), 'defining' the 'basic features' of southern Iberian ditched enclosures became a rather cumbersome task.

\section{THE EXPLANATION OF CHANGE IN IBERIAN COPPER AGE RESEARCH: EXTERNAL VS INTERNAL FACTORS}

The realisation that research on ditched sites could benefit from broader perspectives of enquiry did not occur in Iberia until the early 2000s (Delibes 2001, 300-1; Márquez-Romero 2001; a not very successful earlier attempt in Martín de la Cruz 1997). It appears evident that the late discovery of Iberian ditched sites, together with the prevalence of somewhat inefficient methods that did not facilitate their recognition as enclosures, as well as the low quality of published data, had a big impact on this. However, comparisons with other European areas suggest that other factors were involved in this process. For example, in Denmark, like in Iberia, Neolithic ditched enclosures were discovered relatively late, in the late 1960s and 1970s. Initially, they were researched without systematic use of wide coverage 
survey techniques. Enclosures did not show up well from the air due to the prevailing regional geology, and, 'consequently, we are in general left with the slow and laborious method of excavation as the only means of detecting new sites' (Madsen 1988, 301). With the exception of Sarup (Andersen 1997), most have been published in short, interim reports (Andersen 2002, 2). In spite of this, Scandinavian archaeologists very soon began working under the premise that the causewayed camps of Scandinavia correspond in type and date to those in Central and Western Europe' (Andersen 1982; see also Madsen 1988, 332-3), and quickly joined the wider European discussions (eg, Andersen 1988; 1997; 2002; Madsen 1988).

One could think that Iberian archaeologists are not or have never been very interested in European prehistory, but that would be an absolute misconception. For example, most Iberian researchers have traditionally accepted that, one way or another, directly or indirectly, the process of Neolithisation involved the participation of ideas (or peoples) coming from outside the peninsula. But because the arrival of Neolithic things and practices occurred much earlier, in the 6th millennium cal $\mathrm{BC}$, than in most regions of Western Europe it is, for the most part, seen as unrelated to the monumental enclosures problem. In fact, both megalithic tombs and ditched enclosures have traditionally been viewed as key aspects not of Neolithisation, but of the transition to the Copper Age in the late 4th millennium $\mathrm{BC}$, meaning the introduction of metallurgy, the intensification of agricultural production and, eventually, the emergence of social complexity.

The consideration of both megaliths and ditched enclosures primarily as Copper Age phenomena is important but not decisive. For a very long time, before the discovery of ditched enclosures, the southern Iberian Copper Age was typically identified by the appearance of the so-called Los Millares/Vila nova de São Pedro culture, characterised mainly by the construction of stone masonry walled enclosures (for an overview of their history of research and interpretation, see Chapman 1990, chap. 2; Jorge 1994; 2003a). Los Millares, a 3rd millennium cal BC walled enclosure in south-eastern Spain discovered in the late 19th century, was widely seen as the best example of the transformations that accompanied the introduction of metallurgy of copper in the peninsula, including fortified settlements - the walled enclosures -, new types of objects, and corbelled dome mortuary monuments - tholoi. Sites of the Los Millares/VNSP culture were notably different to any other archaeological site in Iberia and most of Western Europe. That fit very well the then-predominant diffusionist approaches. Hence, for decades, their provenance and the profound changes in society and culture that they were perceived to represent were mostly attributed to external factors, whether they consisted of vague 'influences' or a full-blown process of colonisation organised from the eastern Mediterranean. Thus, research on Iberian Chalcolithic walled enclosures went through a period where comparison and analogy with non-Iberian regions was normal, even desirable.

Awareness of the wider European context has been a characteristic of the study of Iberian megaliths from the outset as well. The discovery of the Dolmen de Menga in Antequera (Malaga, Spain), which triggered the development of multiple studies of Spanish megalithism, took place around the middle of the 19th century. At the time, Menga was analysed side-by-side with monuments all around Western Europe (SánchezCuenca 2012). From that point onwards, whether considered 'Druid', 'Celtic', 'prehistoric', 'oriental' or, later, simply 'megalithic', researchers kept looking at the issue from a broad perspective. Today, most contemporary approaches to the study of Iberian megaliths (eg, García Sanjuán 2009; Boaventura 2011), while acknowledging the immense diversity of the phenomenon, also recognise the existence of a widespread tradition of megalithic architectures in the Neolithic and Chalcolithic of Western Europe. This premise actually enables understanding of the particularities of the Iberian case. What is more, research carried out elsewhere in Europe is seen as a legitimate source of ideas, methods, and experiences.

In my view, this curious discrepancy can be explained as a matter of timing. Unlike megaliths or walled enclosures, which were recorded for the first time in the 19th century, the discovery of the first ditched sites in Andalusia during the 1970s and 1980s coincided with the decline of diffusionism as the preferred source of inspiration in explanations for the advent of the Iberian Copper Age. The collapse of the diffusionist models from the 1970s onwards brought about a certain reaction against diffusionist explanations of change in both Spanish and Portuguese Chalcolithic archaeology. Studies on Iberian megaliths were affected by this paradigm shift, but not to the point of isolating the Iberian evidence from the 


\section{V.J. Jimenez-Jaimez. UNSUSPECTED CIRCLES: S. IBERIAN DITCHED ENCLOSURES}

wider European evidence, probably because the similarities in form and chronology had been obvious for a very long time; by then these ideas were too wellestablished within the Portuguese and Spanish academic milieux. But the evidence in favour of an external origin of other Copper Age 'traits', such as walled enclosures or tholoi, was much weaker and easier to challenge (eg, Chapman 1990, chap. 2). Said reaction against diffusionism was not necessarily very strong or explicit, but a majority of Iberian archaeologists turned their attention to internal processes of evolution starting at the end of the Neolithic (Jorge 1994, 455). External contacts or influences, therefore, were slowly but surely deemed either non-existent or irrelevant. It is exactly at this point that ditched enclosures began to be discovered in Iberia. Unlike in Denmark, there was no perceived necessity to look outside the peninsula in search of comparable examples or possible connections for the newly identified ditched sites (Márquez-Romero \& Jiménez-Jáimez $2010 \mathrm{~b}, 27)$. With that, ideas and methods were also left behind.

\section{CONCLUDING REMARKS}

The importance of ditched enclosures for the prehistory of the Iberian Peninsula is unparalleled elsewhere in Europe. Dozens of confirmed or probable sites are known, and because certain Iberian enclosures had many ditched circuits, the total number of enclosing ditches might be one of the highest in Europe. Especially at some long-lived places, both enclosed areas and constructional elements were truly monumental, suggesting huge investments of work and, therefore, the need for gathering big labour forces. The volume of cultural material elements filling both ditches and pits can hardly be calculated at the moment, but it is presumably outstanding. Thus, it is easy to see their relevance in the dynamics of social and political change in late prehistoric Southern Iberia. With that in mind, it seems paradoxical that, for decades, Iberia was a forgotten region in the European discussion about Neolithic monumental enclosures. Throughout this paper some possible causes for this have been suggested.

The discovery of ditched enclosures occurred much later in Iberia than in other European regions. Years after, they still had not been characterised as enclosures, due to the predominance of excavations initially small, later larger scale - over methods including aerial and geophysical survey that can provide a wider and, given the vast size of many of these sites, clearer perspective. The intricate nature of the southern Iberian archaeological record did not make things easier. Certain southern Iberian sites witnessed human activity for very long periods, resulting in the digging of numerous ditches, as well as countless pits in and around the enclosures, with a marked diachronic character in their construction. Finally, the paradigm shift that accompanied the transformation of the concept of the Iberian Copper Age from a Culture History, diffusion-oriented category, to one which emphasised internal processes of evolution, had an effect on this, not least because it occurred precisely at the same time the first ditched sites were being discovered in southern Iberia.

It can be argued then, that because of both late discovery and insufficient characterisation, the Iberian discussion on the matter of prehistoric ditched enclosures was still in its infancy only a few years ago. When compared to debates elsewhere in Europe, it could be described as less mature, with positions grounded on less data and substantially less years of experience. However, it has developed at a much more rapid pace, driven both by fast growth in the amount of available data, including remote sensing, and by competing theoretical approaches and interpretations. Today, it is moving so fast that it is actually hard to keep track of the new developments.

It is time, therefore, for the integration of Iberian debates into the European scene. This would not mean, in any way, a return to old-fashioned diffusionism with empty analogies based on purely formal similarities or parallels. Quite the contrary, what is argued here is the need to understand local and regional processes of change, whether they are the emergence of enclosures or the construction of megaliths, within a broader frame of reference (Scarre 2013, 382). Multi-scalar approaches, which combine a focus on specific phenomena with an awareness of the wider context in which such phenomena appear and develop, are required for that. This would greatly benefit Iberian research in terms of ideas and methods (Jorge 2003b, 16). But, given the unique problems and challenges which Iberian enclosures pose to archaeologists, it would also constitute a very positive contribution to general discussions. Hopefully this paper can help bridge the existing divide. 
Acknowledgements: This research has been funded by the European Commission through the Marie Curie Actions of the 7th Framework Programme (Intra-European Fellowship), as part of the IBERENCLOGIS project (PIEFGA-2012-326129). I am very grateful to Alasdair Whittle, Chris Scarre, David Wheatley and José Márquez Romero, who kindly read previous versions of this paper and made useful comments on them. I would also like to thank the anonymous reviewers and the PPS editor, Julie Gardiner, for helping me improve this paper with their critiques and suggestions. I remain responsible for any mistake or omission, nonetheless.

\section{BIBLIOGRAPHY}

Andersen, N.H. 1982. A Neolithic Causewayed Camp at Trelleborg near Slagelse, West Zealand. Journal of Danish Archaeology 1, 31-3

Andersen, N.H. 1988. The Neolithic Causewayed enclosures at Sarup, on South-West Funen, Denmark. In Burgess et al. (eds) 1988, 337-62

Andersen, N.H. 1997. Sarup vol. 1. The Sarup Enclosures. Moesgaard: Jutland Archaeological Society

Andersen, N.H. 2002. Neolithic Enclosures of Scandinavia. In Varndell \& Topping (eds) 2002, 1-10

Arnaud, J.M. 1993. O povoado calcolítico de Porto Torrão (Ferreira do Alentejo): síntese das investigações realizadas. Vipasca. Arqueologia e História 2, 41-60

Arnaud, J.M., Martins, A. \& Neves, C. (eds) 2013. Arqueologia em Portugal: 150 Anos. Lisboa: Associação dos Arqueólogos Portugueses

Becker, H., Valera, A.C. \& Castanheira, P. 2012. Monte Do Olival 1 (Ferreira do Alentejo, Beja): Magnetometria de Césio num recinto de fossos do $3^{\circ}$ Milénio AC. Apontamentos de Arqueologia e Património 8, 11-17

Bernabeu, J. (ed) 1993. El III milenio a.C. en el País Valenciano. Los poblados de Jovades (Concentaina) y Arenal de la Costa (Ontinyent). Valencia: Saguntum 26

Bernabeu, J., Pascual, J.L., Orozco, T., Badal, E., Fumanal, M.P. \& García, O. 1994. Niuet (l'Alqueria d'Asnar). Poblado del III milenio a.C. Recerques del Museu d'Alcoi 3, 9-74

Bernabeu, J., Orozco, T., Díez, A., Gómez, M. \& Molina, F.J. 2003. Mas d'Is (Penàguila, Alicante): Aldeas y recintos monumentales del Neolítico Inicial en el Valle del Serpis. Trabajos de Prehistoria 60(2), 39-59

Boaventura, R. 2011. Chronology of megalithism in south central Portugal. In L. García Sanjuán, C. Scarre \& D. Wheatley (eds), Exploring Time and Matter in Prehistoric Monuments: Absolute Chronology and Rare Rocks in European Megaliths, 159-90. Antequera: Menga Monographic Series 1

Braasch, O. 2002. Aerial survey and Neolithic enclosures in Central Europe. In G. Varndell \& P. Topping (eds) 2002, 63-8

Bradford, J. \& Williams-Hunt, P.R. 1946. Siticulosa Apulia. Antiquity 80, 191-200
Bradley, R. 2007. The Prehistory of Britain and Ireland. Cambridge: Cambridge University Press

Bréart, B. (ed) 1999. Actes du colloque international d'archéologie aérienne d'Amiens, 15-18 Octobre 1992. Hommage à Roger Agache. Amiens: Revue Archéologique de Picardie 17

Brophy, K. 2005. Revealing Neolithic Europe. The impact of aerial reconnaissance. In J. Bourgeois \& M. Meganck (eds), Aerial Photography and Archaeology 2003. A Century of Information, 49-61. Ghent: Archaeological Reports Ghent University 4

Burgess, C., Topping, P., Mordant, C. \& Maddison, M. (eds). 1988. Enclosures and Defences in the Neolithic of Western Europe. Oxford: British Archaeological Report S403

Castro, M., Zafra, N. \& Hornos, F. 2008. El lugar de Marroquíes Bajos (Jaén, España). Localización y ordenación interna. Era-Arqueologia 8, 148-57

Chapman, R. 1990. Emerging Complexity. The later prehistory of south-east Spain, Iberia and the west Mediterranean. Cambridge: Cambridge University Press

Curwen, E.C. 1930. Neolithic camps. Antiquity 4, 22-54

Darvill, T. \& Thomas, J. (eds). 2001a. Neolithic Enclosures In Atlantic Northwest Europe. Oxford: Oxbow Books

Darvill, T. \& Thomas, J. 2001b. Neolithic enclosures in Atlantic northwest Europe: some recent trends. In Darvill \& Thomas (eds) 2001a, 1-23

Déchelette, J. 1924. Manuel d'archéologie préhistorique, celtique et gallo-romain. I. Archéologie préhistorique. Paris: Auguste Picard

Delibes, G. 2001. Del Bronce al Hierro en el Valle del Duero: una valoración del límite Cogotas I Soto de Medinilla a partir de las manifestaciones de culto. Zephyrus 53-4, 293-309

Delibes, G., Crespo, M., Fernández, J., Herrán, J.I. \& Rodríguez, J.A. 2009. Stonehenge en Tierra de Campos? Excavaciones en el yacimiento de la Edad del Cobre de El Casetón de la Era (Villalba de Los Alcores, Valladolid). In Conocer Valladolid. II Curso de Patrimonio Cultural 2008/09, 15-33. Valladolid: Real Academia de Bellas Artes de la Purísima Concepción and Ayuntamiento de Valladolid

Delibes, G., Crespo, M., Fernández, J., Herrán, J.I. \& Rodríguez, J.A. 2010. Un recinto de fosos calcolítico en el Valle Medio del Duero: El Casetón de la Era (Villalba de Los Alcores, Valladolid). In Actas de las IV Jornadas sobre Patrimonio Arqueológico de la Comunidad de Madrid, 239-47. Madrid: Comunidad de Madrid and Dirección General de Patrimonio Histórico

Delibes, G., García, M., del Olmo, J. \& Santiago, J. 2014. Recintos de fosos calcolíticos del Valle Medio del Duero. Arqueología aérea y espacial. Valladolid: Ediciones Universidad de Valladolid

Díaz-del-Río, P. 2003. Recintos de Fosos del III Milenio AC en la Meseta Peninsular. Trabajos de Prehistoria 60(2), 61-78

Díaz-del-Río, P. 2004. Copper Age ditched enclosures in central Iberia. Oxford Journal of Archaeology 23(2), $107-21$ 


\section{V.J. Jimenez-Jaimez. UNSUSPECTED CIRCLES: S. IBERIAN DITCHED ENCLOSURES}

Fernández, F. \& Oliva, D. 1980. Los ídolos calcolíticos del Cerro de la Cabeza (Valencina de la Concepción, Sevilla). Madrider Mitteilungen 21, 20-44

Fernández, F. \& Oliva, D. 1985. Excavaciones en el yacimiento calcolítico de Valencina de la Concepción (Sevilla). El Corte C (La Perrera). Noticiario Arqueológico Hispánico 21, 7-131

Fernández, F. \& Oliva, D. 1986. Valencina de la Concepción (Sevilla). Excavaciones de urgencia. Revista de Arqueología 58, 19-33

Fidalgo, C. \& Oosterbeek, L. (eds) 2010. Proceedings of the XVth UISPP World Congress (Lisbon, 4-9 September 2006) vol. 47. Oxford: British Archaeological Report S2124

García Sanjuán, L. 2009. Introducción a los sitios y paisajes megalíticos de Andalucía. In L. García Sanjuán \& B. Ruiz (eds), Las grandes piedras de la Prehistoria. Sitios y paisajes megaliticos de Andalucía, 12-31. Antequera: Junta de Andalucía

García Sanjuán, L. 2013. El asentamiento de la Edad del Cobre de Valencina de la Concepción; estado actual de la investigación, debates y perspectivas. In L. García Sanjuán, J.M. Vargas, V. Hurtado, M.T. Ruiz \& R. Cruz-Auñón (eds), El Asentamiento Prehistórico de Valencina de La Concepción (Sevilla): investigación y tutela en el 150 aniversario del descubrimiento de La Pastora, 21-59. Sevilla: Universidad de Sevilla

Gibaja, J.F, Crespo, M., Delibes, G., Fernández, J., Fraile, C., Herrán, J.I., Palomo, A. \& Rodríguez, J.A. 2012. El uso de trillos durante la Edad del Cobre en la Meseta Española. Análisis traceológico de una colección de denticulados de sílex procedentes del 'recinto de fosos' de El Casetón de la Era (Villalba de Los Alcores, Valladolid). Trabajos de Prehistoria 69(1), 133-48

Gómez Saucedo, M.T. 2003. Excavaciones arqueológicas realizadas en el solar de la Plazuela de Santiago n ${ }^{\circ}$ 6-7 de Carmona (Sevilla). Anuario Arqueológico de Andalucía 2000(III), 1245-56

Hašek, V. \& Kovárník, J. 1999. Aerial and geophysical prospection in archaeological research of prehistoric circular ditches in Moravia. Archaeological Prospection 6, 187-209

Hodgson, J. 1988. Neolithic enclosures in the Isar valley, Bavaria. In Burgess et al. (eds) 1988, 363-89

Hornos, F., Nocete, F. \& Pérez, C. 1987. Actuación arqueológica de urgencia en el yacimiento de Los Pozos en Higuera de Arjona (Jaén). Anuario Arqueológico de Andalucía 1986(3), 198-202

Hornos, F., Zafra, N. \& Castro, M. 1998. La gestión de una zona arqueológica urbana: la experiencia de investigación aplicada en Marroquíes Bajos (Jaén). PH Boletín del Instituto Andaluz de Patrimonio Histórico 22, 82-91

Hurtado, V. 1986. El Calcolítico en la cuenca media del Guadiana y la necrópolis de La Pijotilla. In G. Muñoz Carballo (ed) Actas de la Mesa Redonda sobre Megalitismo Peninsular, 51-77. Madrid: Asociación Española de Amigos de la Arqueología
Hurtado, V. 1991. Informe de las excavaciones de urgencia en La Pijotilla (Badajoz). Extremadura Arqueológica II, 45-68

Hurtado, V. 2003. Fosos y fortificaciones entre el Guadiana y Guadalquivir en el III milenio AC: evidencias del registro arqueológico. In Jorge (ed.) 2003c, 242-68

Hurtado, V. 2008. Los recintos con fosos en la Cuenca Media del Guadiana. Era-Arqueologia 8, 182-97

Jorge, S.O. 1994. Colónias, fortificações, lugares monumentalizados. Trajectória das concepções sobre um tema do Calcolítico peninsular. Revista da Faculdade de Letras II Serie 11, 447-546

Jorge, S.O. 2003a. Revisiting some earlier papers on the late prehistoric walled enclosures of the Iberian Peninsula. Journal of Iberian Archaeology 5, 89-135

Jorge, S.O. 2003b. Pensar o espaço da Pré-História recente: a propósito dos recintos murados da Península Ibérica. In S.O. Jorge (ed.) 2003c, 13-50

Jorge, S.O. (ed.). 2003c. Recintos Murados da Pré-Historia Recente. Porto: Universidade do Porto

Lago, M. \& Albergaria, J. 2001. O Cabeço do Torrão (Elvas): contextos e interpretaçoes previas de um lugar do Neolítico Alentejano. Era-Arqueologia 4, 39-63

Lago, M., Duarte, C., Valera, A.C., Albergaria, J., Almeida, F. \& Carvalho, A. 1998. Povoado dos Perdigões (Reguengos de Mosaraz): dados preliminares dos trabalhos arqueológicos realizados em 1997. Revista Portuguesa de Arqueología 1(1), 45-152

Lechuga, M., Soto, M. \& Rodríguez Ariza, M.O. 2014. El poblado calcolítico "Venta del Rapa" (finales III milenio cal. BC.), Mancha Real, Jaén. Un recinto de fosos entre las estribaciones de Sierra Mágina y el Alto Guadalquivir. Trabajos de Prehistoria 71(2), 353-67

Lizcano, R. 1999. El Polideportivo de Martos (Jaén): un yacimiento neolitico del IV Milenio A.C. Nuevos datos para la reconstrucción del proceso histórico del Alto Guadalquivir. Córdoba: Cajasur

Lizcano, R., Camara, J.A., Riquelme, J.A., Cañabate, M.L., Sanchez, A. \& Afonso, J.A. 1991-2. El Polideportivo de Martos. Producción económica y símbolos de cohesión en un asentamiento del Neolítico Final en las campiñas del Alto Guadalquivir. Cuadernos de Prehistoria de la Universidad de Granada 16-17, 5-101

Madsen, T. 1988. Causewayed enclosures in south Scandinavia. In Burgess et al. (eds) 1988, 301-36

Márquez-Romero, J.E. 2001. 'De los campos de silos a los agujeros negros': sobre fosas, depósitos y zanjas en la prehistoria reciente del sur de la Península Ibérica. Spal 10, 207-20

Márquez-Romero, J.E. 2003. Recintos Prehistóricos Atrincherados (RPA) en Andalucía (España): una propuesta interpretativa. In S.O. Jorge (ed.) 2003c, 269-84

Márquez-Romero, J.E. 2006. Neolithic and Copper Age ditched enclosures and social inequality in the Iberian South (IV-III millennia cal BC). In P. Díaz-del-Río \& L. García Sanjuán (eds), Social Inequality in Iberian Late Prehistory, 171-87. Oxford: British Archaeological Report S1525 
Márquez-Romero, J.E. 2007. La problemática de los recintos de fosos de la Prehistoria reciente en el sur de España. In S.O. Jorge, A.M. Bettencourt \& I. Figueiral (eds), A concepção das paisagens e dos espaços na arqueologia da Península Ibérica. Actas do IV Congresso de Arqueologia Peninsular, 27-35. Faro: Centro de Estudos de Património Promontoria Monográfica

Márquez-Romero, J.E. \& Fernández Ruiz, J. 2002. Viejos depósitos, nuevas interpretaciones: la estructura $\mathrm{n}^{\circ} 2$ del yacimiento prehistórico de Los Villares de Algane (Coín, Málaga). Mainake 21-2, 301-33

Márquez-Romero, J.E. \& Jiménez-Jáimez, V. 2010a. Ten keys to think southern Iberian ditched enclosures. In Fidalgo \& Oosterbeek (eds) 2010, 143-9

Márquez-Romero, J.E. \& Jiménez-Jáimez, V. 2010b. Recintos de Fosos. Genealogía y significado de una tradición en la prehistoria del suroeste de la Península Ibérica (IV-III Milenios AC). Málaga: Servicio de Publicaciones de la Universidad de Málaga

Márquez-Romero, J.E. \& Jiménez-Jáimez, V. 2013. Monumental ditched enclosures in Southern Iberia (fourth-third millennia cal BC). Antiquity 87(336), 447-60

Márquez-Romero, J.E. \& Jiménez-Jáimez, V. 2014. Space and time in the architecture of Prehistoric enclosures. The Iberian Peninsula as a case study. In E. Souvatzi \& A. Hadji (eds), Space and Time in Mediterranean Prehistory, 214-30. London/New York: Routledge

Márquez-Romero, J.E., Valera, A.C., Becker, H., JiménezJáimez, V. \& Suárez, J. 2011. El Complexo Arqueológico dos Perdigões (Reguengos de Monsaraz, Portugal). Prospecciones Geofísicas - Campañas 2008-09. Trabajos de Prehistoria 68(1), 175-86

Martín de la Cruz, J.C. 1985. Papa Uvas I. Aljaraque, Huelva. Campañas de 1976 a 1979. Madrid: Excavaciones arqueológicas en España 136

Martín de la Cruz, J.C. 1986. Papa Uvas II. Aljaraque, Huelva. Campañas de 1981 a 1983. Madrid: Excavaciones arqueológicas en España 149

Martín de la Cruz, J.C. 1997. Types of fortification in sites in Southern Italy and Spain during the Neolithic and Cooper Ages. In M. Balmuth, A. Gilman \& L. Prados-Torreira (eds), Encounters and Transformations. The Archaeology of Iberia in Transition, 15-23. Sheffield: Sheffield Academic Press

Musson, C. 2013. Part 1: Flights into the past. In C. Musson, R. Palmer \& S. Campana (eds), Flights into the Past. Aerial Photography, Photo Interpretation and Mapping for Archaeology, 11-54. Aerial Archaeology Research Group/ArchaeoLandscapes Europe (ArcLand) Project of the European Union Occasional Publication No. 4

Olmo, J. 1999. Arqueología aérea en tres ciudades indígenas romanizadas. In Los orígenes de la ciudad en el noroeste hispánico: Actas del Congreso Internacional (Lugo 1996), 409-28. Lugo: Diputación Provincial

Orozco, T. 2009. Recintos de Fosos. Panorama Europeo. In Actas de las IV Jornadas sobre Patrimonio Arqueológico de la Comunidad de Madrid, 172-81.
Madrid: Comunidad de Madrid and Dirección General de Patrimonio Histórico

Oswald, A., Dyer, C. \& Barber, M. 2001. The Creation of Monuments. Neolithic Causewayed Enclosures in the British Isles. London: English Heritage

Rojo, M., Kunst, M., Garrido, R., García, I. \& Morán, G. 2008. Paisajes de la memoria: asentamientos del Neolítico Antiguo en el Valle de Ambrona (Soria, España). Valladolid: Universidad de Valladolid

Ruiz Lara, D. 1991. Excavación arqueológica de urgencia en La Minilla (La Rambla, Córdoba). Campaña de 1989. Anuario Arqueológico de Andalucía 1989(3), 157-63

Ruiz Mata, D. 1983. El yacimiento de la Edad del Cobre de Valencina de la Concepción (Sevilla) en el marco cultural del Bajo Guadalquivir. In Actas del I Congreso de Historia de Andalucía. Prehistoria y Arqueología, 183-208

Sánchez-Cuenca, J.I. 2012. Menga en el siglo XIX: el más bello y perfecto de los dólmenes conocidos. Antequera: Menga Monographic Series 2

Scarre, C. 2013. Social Stratification and the State in Prehistoric Europe: The Wider Perspective. In M. Cruz Berrocal, L. García Sanjuán \& A. Gilman (eds), The Prehistory of Iberia: debating early social stratification and the state. London/NewYork: Routledge, 381-406

Thomas, J. 1999. Understanding the Neolithic. London: Routledge

Valera, A.C. 2013a. Recintos de fossos da Pré-História Recente em Portugal. Investigação, discursos, salvaguarda e divulgação. Al-Madam Série 2 18, 93-110

Valera, A.C. 2013b. Cronologia dos recintos de fossos da Pré-História Recente em território português. In Arnaud et al. (eds) 2013, 335-43

Valera, A.C. 2013c. Cronologia absoluta dos fossos 1 e 2 do Porto Torrão e o problema da datação de estruturas negativas 'tipo fosso'. Apontamentos de Arqueologia e Património 9, 7-12

Valera, A.C. 2013d. Novos recintos de fossos no sul de Portugal: o Google Earth como ferramenta de prospecção sistemática. In Arnaud et al. (eds) 2013, 345-50

Valera, A.C. \& Evangelista, L. 2010. The idea of enclosure in recent Iberian prehistory. In Fidalgo \& Oosterbeek (eds) 2010, 97

Valera, A.C. \& Filipe, I. 2004. O povoado do Porto Torrão (Ferreira do Alentejo). Era-Arqueologia 6, 28-61

Valera, A.C. \& Filipe, V. 2010. Outeiro Alto 2 (Brinches, Serpa): nota preliminar sobre um espaço funerário e de socialização do neolítico final à Idade do Bronze. Apontamentos de Arqueologia e Património 5, 49-56

Valera, A.C., Becker, H. \& Boaventura, R. 2013. Moreiros 2 (Arronches, Portalegre): geofísica e cronologia dos recintos interiores. Apontamentos de Arqueologia $e$ Património 9, 37-46

Valera, A.C., Silva, A.M. \& Márquez-Romero, J.E. 2014. The temporality of Perdigões enclosures: absolute chronology of the structures and social practices. Spal 23, 11-26

Vargas, J.M. 2004. Carta Arqueológica Municipal de Valencina de la Concepción. Sevilla: Junta de Andalucía 


\section{V.J. Jimenez-Jaimez. UNSUSPECTED CIRCLES: S. IBERIAN DITCHED ENCLOSURES}

Varndell, G. \& Topping, P. (eds) 2002. Enclosures in Neolithic Europe. Essays on Causewayed and Noncausewayed Sites. Oxford: Oxbow Books

Wheatley, D., Strutt, K., García Sanjuán, L, Mora, C. \& Peinado, J. 2012. New evidence on the spatial organisation of the Valencina de la Concepción Copper Age settlement: geophysical survey between La Pastora and Montelirio. Trabajos de Prehistoria 69(1), 65-79

Whittle, A. 1996. Europe in the Neolithic. The Creation of New Worlds. Cambridge: Cambridge University Press

Whittle, A. 2006. The temporality of the enclosure. In V.O. Jorge (ed.), Approaching 'Prehistoric and Protohistoric architectures' of Europe from a 'dwelling perspective'. Proceedings of the TAG Session Sheffield 2005, 15-24. Porto: Adecap

Whittle, A., Healy, F. \& Bayliss, A. 2011. Gathering Time. Dating the Early Neolithic Enclosures of Southern Britain and Ireland. Oxford: Oxbow Books

Zafra, N., Hornos, F. \& Castro, M. 1999. Una macro-aldea en el origen del modo de vida campesino: Marroquíes Bajos (Jaén) c. 2500-2000 cal ANE. Trabajos de Prehistoria 56(1), 77-102

Zafra, N., Castro, M. \& Hornos, F. 2003. Sucesión y simultaneidad en un gran asentamiento: la cronología de la macro-aldea de Marroquíes Bajos, Jaén. c. 2500-2000 cal ANE. Trabajos de Prehistoria 60(2), 79-90

\section{RÉSUMÉ}

Cercles insoupçonnés. Reconnaissance tardive des enclos à fossés du néolithique et du Chalcolithique dans l'Ibérie du sud, de Víctor Jiménez-Jáimez

Les enclos à fossés néolithiques semblent être largement répandus à travers l'Europe centrale et occidentale, et de la région méditerranéenne à la Scandinavie. Nous connaissons leur existence dans certaines zones d'Europe depuis longtemps, mais particulièrement depuis les 25 dernières années, les études sur les enclos à fossés en Grande-Bretagne, France, Europe centrale et Scandinavie ont prospéré. A la suite de cela, ont eu lieu au cours des trois dernières décennies un certain nombre de conférences internationales. Par contraste, dans l'Ibérie méridionale, ce n'est que dans les années 1970 que les enclos à fossés ont commencé à être reconnus, et même à ce moment-là, des déficiences méthodologiques et un manque de financement ont entravé leur caractérisation. Cela a eu pour conséquence que les enclos à fossés ibériens du néolithique et de l'âge du cuivre étaient en grande partie inconnus en dehors du Portugal et de l'Espagne. Ils n'étaient représentés dans aucune des conférences internationales mentionnées ci-dessus, ni inclus dans aucune des synthèses établies sur ce thème. Et ce n'est pas tout, pendant des décennies les archéologues espagnols et portugais eux-mêmes ont ignoré les éventuelles analogies, et les recherches qui étaient en cours ailleurs en Europe n'avaient pratiquement pas d'influence sur la manière dont les enclos à fossés étaient prospectés, fouillés et interprétés dans la péninsule. Le principal objectif de cet article est de promouvoir la reconnaissance des témoignages du sud de la péninsule ibérique par d'autres chercheurs européens et d'intégrer la conversation ibérienne dans la discussion générale. Nous nous concentrerons sur comment ces sites ont été étudiés par plusieurs générations d'archéologues ibériens, pour tenter d'expliquer pourquoi il a fallu si longtemps aux archéologues portugais et espagnols pour se rendre compte que les enclos ibériens ne devraient pas être compris isolément.

\section{ZUSSAMENFASSUNG}

Die unvermuteten Kreise. Zum späten Erkennen von südiberischen Grabenwerken des Neolithikums und Chalkolithikums, von Víctor Jiménez-Jáimez

Neolithische Grabenwerke scheinen in weiten Teilen Mittel- und Westeuropas verbreitet zu sein, wie auch vom Mittelmeer bis Skandinavien. Seit langer Zeit sind sie in europäischen Regionen bekannt, aber insbesondere in den letzten 25 Jahren entstanden zahlreiche Studien zu britischen, französischen, mitteleuropäischen und skandinavischen Grabenwerken. In diesem Zusammenhang wurden in den letzten drei Jahrzehnten auch viele internationale Treffen abgehalten. Im südlichen Iberien sind im Gegensatz hierzu erst seit den 1970er Jahren Grabenwerke bekannt, und selbst dann behinderten methodologische Unzulänglichkeiten und der Mangel an Finanzierung ihre Charakterisierung. In der Konsequenz blieben iberische Grabenwerke des Neolithikums und der Kupferzeit außerhalb Portugals und Spaniens unbekannt. Sie waren bei keinem der erwähnten internationalen Treffen vertreten und auch nicht in eine der Synthesen zu diesem Thema eingeschlossen. Nicht nur das, auch spanische und portugiesische Archäologen erkannten jahrzehntelang die möglichen Analogien 
nicht, so dass die Forschung, die in anderen Teilen Europas stattfand, nahezu keinen Einfluss darauf hatte wie die Grabenwerke auf der Halbinsel aufgenommen, ausgegraben und interpretiert wurden. Das wichtigste Ziel dieses Beitrags ist deshalb, die Kenntnis der südiberischen Befunde bei anderen europäischen Forschern und die Integration der iberischen in die allgemeine europäische Diskussion zu fördern. Der Schwerpunkt liegt auf der Frage, wie diese Befunde durch mehrere Generationen iberischer Archäologen erforscht wurden, um zu erklären zu versuchen, warum portugiesische und spanische Archäologen so lange brauchten um zu erkennen, dass die iberischen Grabenwerke nicht isoliert verstanden werden können.

\section{RESUMEN}

Los círculos insospechados. A propósito del reconocimiento tardío de los recintos de fosos neolíticos y calcoliticos del sur de la Península Ibérica, por Víctor Jiménez-Jáimez

Los recintos de fosos neolíticos, aparentemente, se encuentran ampliamente distribuidos por Europa Central y Occidental. Se conocen en ciertas áreas de Europa desde hace mucho tiempo, pero en los últimos 25 años la investigación sobre los recintos de fosos británicos, franceses, centroeuropeos y escandinavos se ha intensificado. Varias reuniones internacionales han tenido lugar en las últimas tres décadas en relación con ello. Sin embargo, en el sur de la Península Ibérica los recintos de fosos no comenzaron a detectarse hasta los años setenta del siglo $\mathrm{XX}$, e incluso entonces ciertas deficiencias metodológicas y la falta de recursos económicos para su investigación dificultaron su caracterización. Como consecuencia de ello, el conocimiento sobre los recintos de fosos ibéricos del Neolítico y la Edad del Cobre ha continuado siendo muy escaso fuera de Portugal y España. Estos recintos no estuvieron representados en ninguno de los encuentros internacionales mencionados, ni fueron incluidos en ninguna de las síntesis realizadas sobre el tema. No sólo eso, durante décadas los propios arqueólogos españoles y portugueses desconocieron las potenciales analogías, de modo que las investigaciones llevadas a cabo en otras regiones de Europa no tuvieron apenas influencia en la forma en que los recintos de fosos peninsulares eran prospectados, excavados e interpretados. El principal objetivo de este trabajo es avanzar en el reconocimiento, por otros investigadores europeos, de la evidencia arqueológica procedente de la Península Ibérica, así como la integración de los debates ibéricos en la discusión general europea. El artículo se centrará en cómo estos sitios han sido estudiados por varias generaciones de arqueólogos ibéricos, en un intento de explicar por qué los investigadores portugueses y españoles han tardado tanto en comprender que los recintos ibéricos no deberían ser entendidos aisladamente, sino en un contexto más amplio. 